\title{
Complex graphite bearing sample UV-92/03: evolution of rock transformation
}

\author{
Lyudmila N. Pokhilenko, Nikolay P. Pokhilenko \\ V.S.Sobolev Institute of Geology and Mineralogy SB RAN, Novosibirsk, Russia
}

\section{Introduction}

Deep rock xenolith research makes it possible to get very important data on the composition, structure of upper mantle and mantle substance transformations. This work presents a comprehensive investigation of complex graphite bearing sample.

\section{Methods}

Methods of optic microscopy in transmitted and reflected light (MBS-10, Russia; Olympus BX51, Japan), electron scanning microscopy (JEOL JSM 6380LA, Japan), x-ray microprobe analysis (Camebax-micro, France; JEOL JXA-8100, Japan) were used.

\section{Mineral and chemical composition}

Sample UV-92/03 represents partially recrystallized orthopyroxene (enstatite) megacrystal. Large enstatite domains with isometric or elongated garnet, graphite and phlogopite grains are the essentials of the sample. These grains are irregularly distributed in the orthopyroxene matrix. About a half of a sample resembles "graphic granite" in structure because of abundant garnet ingrowths. Garnet occurs as parallel lamellae and elongated or (rarely) isometric grains directed parallel to lamellae or at angles of 45 or $135^{\circ}$.
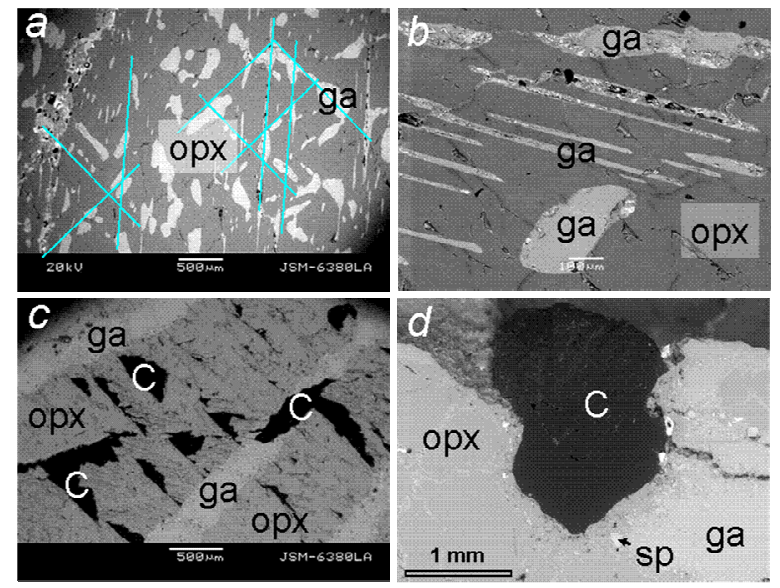

Fig. 1: a, b - garnet (ga) grains and lamellae in the orthopyroxene (opx) matrix, c - garnet lamellae and graphite $(C)$ isolations in the orthopyroxene matrix, $d-$ large graphite grain in the pyroxene matrix.
Graphite occurs as large (up to $2 \mathrm{~mm}$ ) isometric or elongated grains.

Structures with garnet $(\sim 0.5 \mathrm{~mm})$, clinopyroxene, graphite, olivine and phlogopite grains similar to hypidiomorphic grain structure are found in places among the disoriented opx blocks.

The analysis of the opx matrix has shown that opx is represented by a near pure enstatite $(\sim 91.7 \mathrm{~mol} . \%)$ with negligible ferrosilite fraction. However the compositions with 3.5-3.9 wt.\% $\mathrm{Al}_{2} \mathrm{O}_{3}$ are found at the boundaries of garnet grains. There are oval or trapezoid opx inclusions in garnet. The boundaries are flat and well-defined, reaction rims are few. The composition of the inclusions is identical with the composition of opx matrix.

Garnet consists of pyrope ( $\sim 68-70$ mol.\%), almandine ( 12-14 mol.\%), uvarovite ( 6-10 mol.\%), knorringite $(\sim 5-9 \quad \mathrm{~mol} \%)$. Standard $\mathrm{Cr}_{2} \mathrm{O}_{3}-\mathrm{CaO}$ diagram demonstrates the analyzed points within the harzburgite-dunite field.

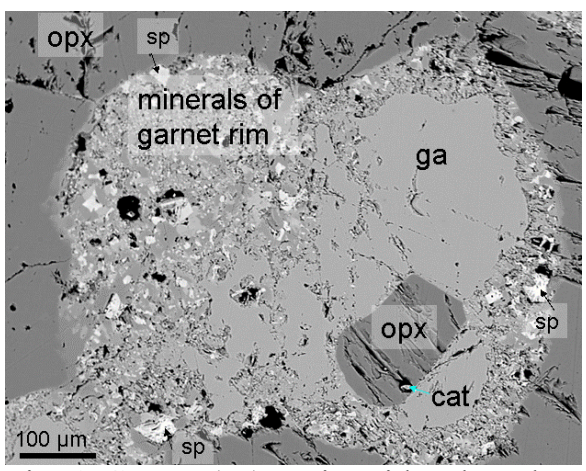

Fig. 2 Garnet (ga) grain with a broad complicated rim in the orthopyroxene (opx). Sp -spinel, cat - calcite.

Garnet grains and lamellae are, as a rule, surrounded by the reaction rims of different thickness (from 0 to 200 $\mu \mathrm{m}$ and more). A rim sometimes completely replaces a garnet grain. The study of the phase composition of these structures using the electron scanning microscope made it possible to identify high-Al spinel, sodalite, potassium feldspar, apatite, clinopyroxene and phlogopite. Detailed microprobe study has shown that a number of the phases intermediate between garnet and pyroxene occur in the rims around the garnet. Microprobe analyses of the whole spectrum of the 
minerals of transitional composition are given in the Table.

\begin{tabular}{|c|c|c|c|c|c|c|}
\hline $\mathrm{SiO}_{2}$ & 41.3 & 43.70 & 45.81 & 47.62 & 49.70 & 50.49 \\
\hline $\mathrm{TiO}_{2}$ & 0.05 & 0.04 & 0.04 & 0.02 & 0.04 & 0.05 \\
\hline $\mathrm{Al}_{2} \mathrm{O}_{3}$ & 19.51 & 15.17 & 16.60 & 12.23 & 8.94 & 11.44 \\
\hline $\mathrm{Cr}_{2} \mathrm{O}_{3}$ & 5.40 & 5.04 & 4.49 & 3.52 & 2.43 & 2.47 \\
\hline $\mathrm{MnO}$ & 0.27 & 0.26 & 0.29 & 0.28 & 0.34 & 0.31 \\
\hline $\mathrm{FeO}$ & 7.15 & 7.32 & 7.08 & 7.34 & 7.06 & 6.73 \\
\hline $\mathrm{MgO}$ & 21.62 & 25.53 & 25.15 & 26.85 & 29.17 & 26.71 \\
\hline $\mathrm{CaO}$ & 3.82 & 2.31 & 1.39 & 1.58 & 1.36 & 1.68 \\
\hline $\mathrm{Na}_{2} \mathrm{O}$ & 0.05 & 0.00 & 0.07 & 0.03 & 0.05 & 0.04 \\
\hline $\mathrm{K}_{2} \mathrm{O}$ & 0.00 & 0.01 & 0.05 & 0.03 & 0.02 & 0.00 \\
\hline Total & 99.16 & 99.35 & 100.97 & 99.50 & 99.12 & 99.91 \\
\hline $\mathrm{SiO}_{2}$ & 51.95 & 52.68 & 53.09 & 54.58 & 55.84 & 58.18 \\
\hline $\mathrm{TiO}_{2}$ & 0.02 & 0.02 & 0.13 & 0.04 & 0.03 & 0.02 \\
\hline $\mathrm{Al}_{2} \mathrm{O}_{3}$ & 7.28 & 6.48 & 6.16 & 3.65 & 3.89 & 0.48 \\
\hline $\mathrm{Cr}_{2} \mathrm{O}_{3}$ & 1.74 & 1.21 & 1.31 & 0.82 & 1.13 & 0.34 \\
\hline $\mathrm{MnO}$ & 0.36 & 0.28 & 0.20 & 0.24 & 0.15 & 0.08 \\
\hline $\mathrm{FeO}$ & 7.51 & 7.28 & 6.62 & 6.02 & 5.40 & 4.49 \\
\hline $\mathrm{MgO}$ & 29.18 & 30.29 & 31.51 & 32.28 & 34.42 & 35.76 \\
\hline $\mathrm{CaO}$ & 1.40 & 1.26 & 0.61 & 1.22 & 0.59 & 0.24 \\
\hline $\mathrm{Na}_{2} \mathrm{O}$ & 0.14 & 0.08 & 0.12 & 0.13 & 0.11 & 0.15 \\
\hline $\mathrm{K}_{2} \mathrm{O}$ & 0.01 & 0.00 & 0.10 & 0.30 & 0.00 & 0.00 \\
\hline Total & 99.58 & 99.59 & 99.85 & 99.28 & 101.55 & 99.74 \\
\hline $\mathrm{SiO}_{2}$ & 41.30 & 48.85 & 49.78 & 51.32 & 52.65 & 52.54 \\
\hline $\mathrm{TiO}_{2}$ & 0.05 & 0.06 & 0.055 & 0.07 & 0.16 & 0.04 \\
\hline $\mathrm{Al}_{2} \mathrm{O}_{3}$ & 19.51 & 8.25 & 6.83 & 7.97 & 5.59 & 1.12 \\
\hline $\mathrm{Cr}_{2} \mathrm{O}_{3}$ & 5.40 & 3.00 & 2.1 & 1.72 & 0.60 & 0.26 \\
\hline $\mathrm{MnO}$ & 0.27 & 0.27 & 0.36 & 0.23 & 0.19 & 0.14 \\
\hline $\mathrm{FeO}$ & 7.15 & 4.49 & 4.33 & 3.97 & 3.94 & 3.15 \\
\hline $\mathrm{MgO}$ & 21.62 & 16.10 & 16.14 & 15.92 & 17.45 & 25.27 \\
\hline $\mathrm{CaO}$ & 3.82 & 17.51 & 17.87 & 17.24 & 18.20 & 16.56 \\
\hline $\mathrm{Na}_{2} \mathrm{O}$ & 0.05 & 0.58 & 0.96 & 0.88 & 0.93 & 0.44 \\
\hline $\mathrm{K}_{2} \mathrm{O}$ & 0.00 & 0.02 & 0.00 & 0.26 & 0.06 & 0.00 \\
\hline Total & 99.16 & 99.13 & 98.42 & 99.56 & 99.75 & 99.53 \\
\hline
\end{tabular}

Rim minerals become larger in some cases as they move away from the garnet grain and appear to be independent grains in the opx-matrix or intergrain space.

Chromespinelides from the garnet rim differ in composition and usually in size from the independent spinelide grains in the pyroxene matrix or intergranular areas. The first ones are smaller (up to $70 \mu \mathrm{m}$ ), essentially alumina (45-55 wt.\% $\mathrm{Al}_{2} \mathrm{O}_{3}$ ) and magnesia (19-22 wt.\% $\mathrm{MgO}$ ) with weak direct zonality. The second (up to 100-200 $\mu \mathrm{m}$ ) are more chromium (40-44 wt.\% $\mathrm{Cr}_{2} \mathrm{O}_{3}$ ) and contain 2.5-3 wt.\% $\mathrm{TiO}_{2}$. A grain with distinct zonality was analyzed among the second group of spinelides : center - 28.81 wt. $\% \mathrm{Al}_{2} \mathrm{O}_{3} ; 40.19$ wt. $\% \mathrm{Cr}_{2} \mathrm{O}_{3} ; 13.26$ wt. $\% \mathrm{FeO} ; 16.59$ wt. $\% \mathrm{MgO}$; edge - 38.70 wt. $\% \mathrm{Al}_{2} \mathrm{O}_{3} ; 30.09$ wt. $\% \mathrm{Cr}_{2} \mathrm{O}_{3} ; 12.08$ wt.\% $\mathrm{FeO} ; 17.98$ wt.\% MgO. Isolated spinelide grain (Sp3) near the rim has an intermediate composition with similar chrome and alumina (35 wt.\%), magnesium and ferrum (15 wt.\%) content.

Phlogopite is present in orthopyroxene both as ingrowths (up to $1 \mathrm{~mm}$ ), bordering garnet grains or lamellae, and as small grains or fine-grain masses in the intergrain space or cracks. Phlogopite was observed among the minerals of garnet rims. This phlogopite is distinguished by the elevated $\mathrm{TiO}_{2}, \mathrm{Al}_{2} \mathrm{O}_{3}, \mathrm{Cr}_{2} \mathrm{O}_{3}, \mathrm{Na}_{2} \mathrm{O}$ and $\mathrm{FeO}$ content and reduced $\mathrm{SiO}_{2}, \mathrm{MgO}$ content as compared to the phlogopite from the opx matrix. $\mathrm{Cl}$ and $\mathrm{F}$ are found in negligible amounts.

Sylvite $(\mathrm{KCl})$ was found in the sample twice. A grain of $\sim 80 \times 40 \mu \mathrm{m}$ in size was in the intergrain space in contact with phlogopite, orthopyroxene, graphite grains and minerals of garnet rim. Smaller isometric grain resided in the orthopyroxene matrix.

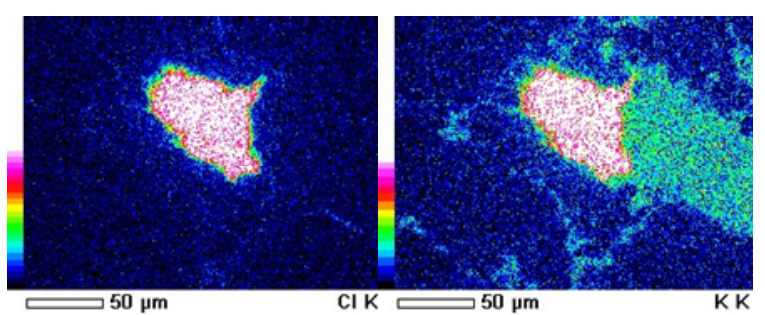

Fig.3 Sylvite in orthopyroxene, phlogopite is plotted to the right.

Apatite isolations from 5 to $25 \mu \mathrm{m}$ in size were found among the minerals of the rim around garnet and as inclusions in phlogopite using the scanning microscope.

Mineral identified as potassium feldspar (using the scanning microscope) occurs among the minerals of garnet rims. Sometimes it fills cracks and fringes phlogopite grains. $\mathrm{Na}_{2} \mathrm{O}$ (4-6 wt.\%) impurity is found in the composition (Fig. 4).

Mineral defined as sodalite is found among the minerals of garnet rims, often at the boundaries of phlogopite or spinelide and other minerals, in the cracks filled with potassium feldspar and phlogopite.
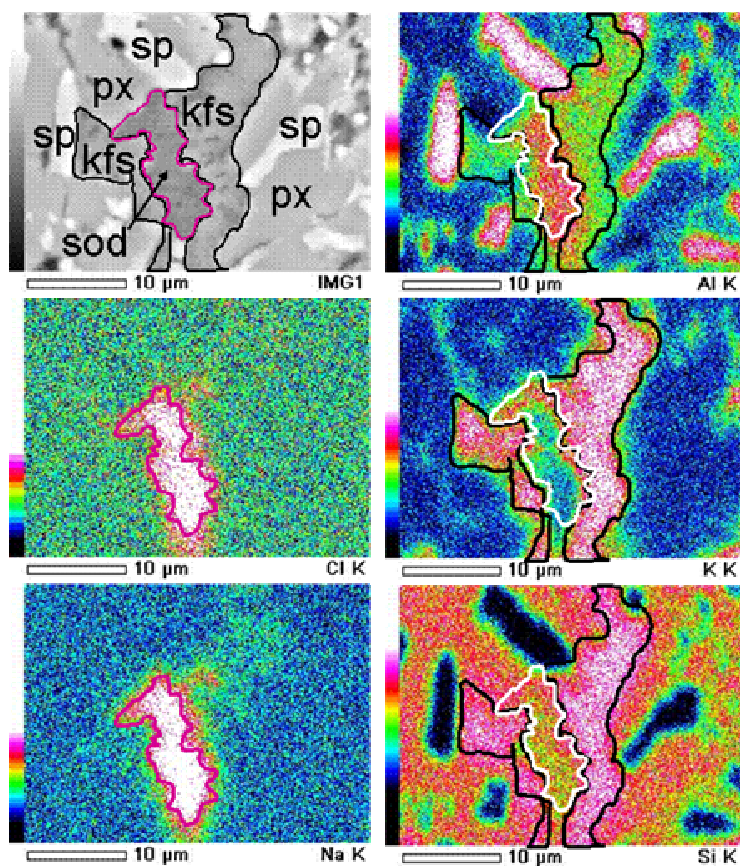

Fig.4 Sodalite (sod) and potassium feldspar (kfs) among the minerals of garnet rim (spinel, pyroxene of transitional composition) 
Olivine grains from $15 \mu \mathrm{m}$ to $80 \mu \mathrm{m}$ in size occur in different parts of the sample: near the broad garnet lamellae with narrow rim, as separate grains, as finegrained masses together with spinelide and clinopyroxene. The composition is constant and forsterite minal prevails ( $92.8 \mathrm{~mol} . \%)$.

Calcite grain of about $15-20 \mu \mathrm{m}$ in size has been found in the orthopyroxene inclusion (Fig. 2).

Sulfides occur in the opx matrix, among the minerals of garnet rims, in the intergrain space, in the cracks

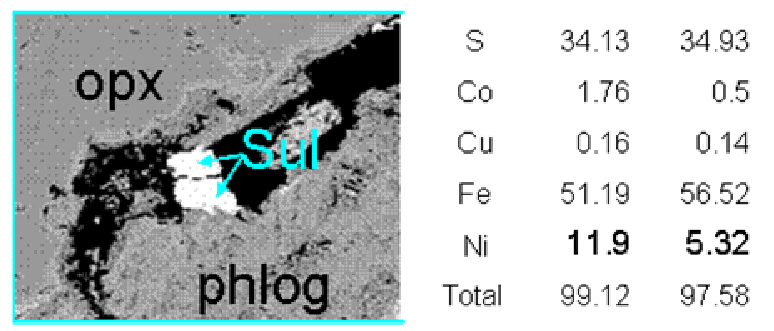

filled with phlogopite, potassium feldspar and sodalite, as inclusions in phlogopite. Sulfides are represented by pyrrhotite (often with $\mathrm{Ni}$ ) and pentlandite. Co (up to $1.76 \mathrm{wt} . \%$ ) and rarely $\mathrm{Cu}$ are at times detected.

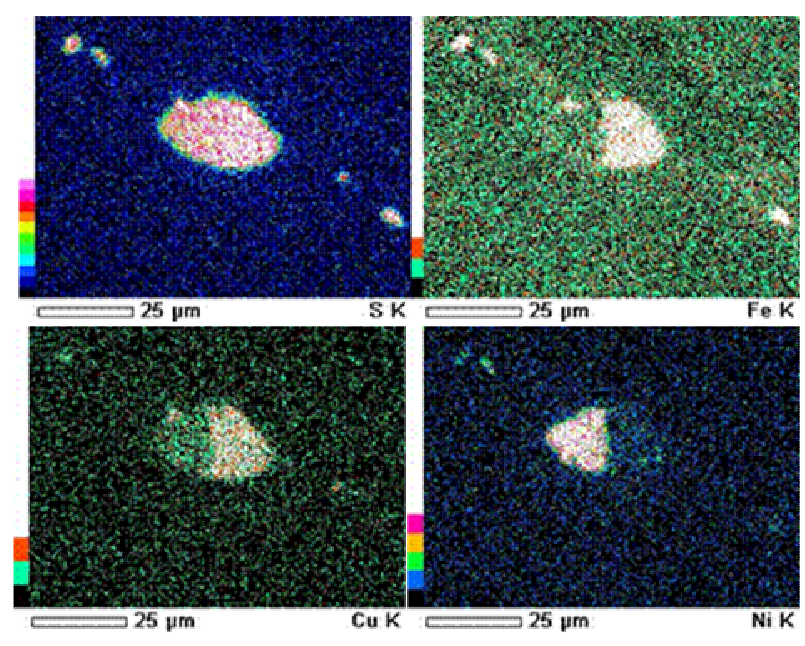

Fig.5 Zonal sulfide in opx

\section{Discussion}

Complicated multiphase composition of the sample suggests its multistage formation. Decomposition of deep-seated high-T orthopyroxene with garnet isolation probably happened by the following scheme:
$2 \mathrm{MgSiO}_{3}$ (enstatites minal) $+\mathrm{MgAl}_{2} \mathrm{SiO}_{6}(\mathrm{Mg}-$ Tschermak minal) $\rightarrow \mathrm{Mg}_{3} \mathrm{Al}_{2} \mathrm{Si}_{3} \mathrm{O}_{12}$ (pyrope).

Further change of PT-parameters and the effect of metasomatic agents probably caused structuralchemical transformations in garnet followed by its conversion to pyroxene as evidenced by garnet rims, which have garnet - orthopyroxene and garnet clinopyroxene transition spectra of compositions.

Zonal spinelides and sodalite have been described in the kimberlite groundmass (Golovin, 2004) and as interstitial minerals of the deformed peridotites from Udachnaya pipe. The authors have interpreted them as products of kimberlite melt infiltration (Golovin et al., 2007). In our case these minerals have been found in the reaction rims around garnet and in the complicated garnet lamellae. This fact is evidence that minerals have been formed before kimberlite traps the rock.

Sodalite in the fresh sample is indicative of chlorine participation in the deep metasomatic processes. The obtained result and previously described evidence of chlorine participation in the generation of protokimberlite melts and formation of definite part of diamonds (Izraeli et al., 2001, Klein-BenDavid et al., 2004) suggest that chlorine participation in the metasomatic changes of lithosphere mantle rocks as a whole calls for further investigation.

High temperature sulfides imply the deep origin of the studied xenolith. However, graphite in the sample suggests that this rock and later processes transforming it have occurred at the depths above $140 \mathrm{~km}$.

\section{References}

Golovin A.V. Peculiarities of melts evolution during kimberlite (Udachnaya-Eastern pipe, Yakutia) and basanite (Bele pipe, Khakasia) crystallization on the data of melt inclusions study: Ph.D thesis, Novosibirsk, 2004, 240p.

Golovin A.V., Sharygin I.S., Pokhilenko N.P. Mineralogy of xenoliths of the deformed garnet lherzolites from Udachnaya-Eastern kimberlite pipe (Yakutia)//Proceedings of the $2^{\text {nd }}$ Kimberlite Konference "Crystallogenesis and Mineralogy", St. Peterburg, 2007, p. 250-252.

Izraeli E.S., Harris J.W., Navon O. Brine inclusions in diamonds: a new upper mantle fluid. // Earth and Planetary Science Letters. - 2001. - V.5807 - P.1-10.

Klien-BenDavid O., Izraeli E.S., Hauri E.H., Navon O. Mantle fluid evolution - a tale of one diamond // Lithos. - 2004. - V.77. - P. 243-253. 